\title{
A COMPARATIVE STUDY ON ENGLISH SPEAKING SKILL BETWEEN INTERPERSONAL AND INTRAPERSONAL STUDENTS IN THE THIRD SEMESTER OF ENGLISH TEACHING LEARNING PROGRAM OF STAIN PAMEKASAN
}

\author{
Moh Syafik ${ }^{1}$ \\ ${ }^{1}$ English Teaching Learning Program, Tarbiyah Faculty, Institut Agama Islam Negeri Madura \\ (mohammadsyafik007@gmail.com) \\ Afifah Raihany ${ }^{2}$ \\ ${ }^{2}$ English Teaching Learning Program, Tarbiyah Faculty, Institut Agama Islam Negeri Madura \\ (afifah@stainpamekasan.ac.id)
}

\begin{abstract}
Students' different intelligence affect different academic achievement, speaking skill as one of the required skills that have to be mastered by students must also be influenced by students' intelligence. This study was mainly purposed to investigate whether there is a significant difference between interpersonal students and intrapersonal students on their English speaking skills. This study uses Ex-post facto or causal-comparative with a quantitative research approach. The population was 216 students of all third-semester students of English Teaching Learning Program of STAIN Pamekasan, the sample of 50 students (25 interpersonal students and 25 intrapersonal students) were taken away by using stratified random sampling. Two research instruments were utilized. The questionnaire was spread out to identify the students' intelligence, while documentation was used to know the result of the summative test of English speaking skills. The research result reveals there is a significant difference between interpersonal students and intrapersonal students in the third semester of the English Teaching Learning Program of STAIN Pamekasan on their English speaking skills. The t-value of 3.86 is significantly higher than the t-table (significant level 5\%) that is only 2.01. (3.86 > 2.01; Level of significance 5\%, $d f=50)$. Interpersonal students are better on English speaking skills because they have special characteristics, such as love to interact, have good communication skills, strong empathy, and good sociability. They are usually outgoing and also easily adaptable make them quick to learn.
\end{abstract}

Keywords: Interpersonal Student; Intrapersonal Student; Speaking Skill

First Received:

Final Proof Received:

(January 28, 2020)

(March 20, 2020)

\section{INTRODUCTION}

Speaking includes as one of the standardized skills that have to be mastered by students besides reading, listening, and writing. Speaking is one of the types of composing in language that is swift, complicated, frequent, and primary because the language itself is symbolic to use by communicators to construct and to convey information (Carter in Ulviana, 2011). Mastering speaking skill is an obligation for all students. They must be trained to use English in communication orally. The frequency in using the language will determine the success in speaking skill. 
Some students think speaking is the most difficult skill in foreign language learning. They face some problems such as shy to speak with their friends using English, afraid of making mistake, afraid to be laughed at by others and do not feel confident. Indeed, speaking is a complicated skill. It does not only involve the grammatical systems such as in writing, but also the phonological systems of language (Widdowson, 1978: 58-59).

The problems above appear because of external and internal factors. Some overlooked internal factors such as talent, motivation, aptitude, and also intelligence factors also "play" there. Yes, Intelligence is an irreplaceable factor that influences the success in academic achievements (include in speaking skills).

Brown says that success in an educational institution and life, in general, seems to be a correlate of high intelligence (Brown, 2007: 108). Linda Campbell and Bruce Campbell claim the same idea, they state the difference between student's achievements is not only influenced by classroom instructions that the teachers apply, but also the intelligence that students have (Cambell \& Cambell, 1999: 3). They, two experts above share the same views that intelligence is one of the most important factors in determining the success of the students.

Let's take a look at the word "intelligence". Traditionally intelligence has been defined based on linguistic and logical-mathematical abilities (Brown, 2007: 108). In the classical view, linguistic and logical intelligence become the two measurements of the students' intelligence. By means, if they are very strong in those intelligence areas, they will be considered as "smart". The linguistic and logical-mathematical intelligence are what's next measured as IQ (intelligence quotient).

However, Howard Gardner encounters this thought. He advanced a controversial theory of Multiple Intelligences (MI). He comes with the new definition of intelligence stating that intelligence as an ability to solve problems or create products that are valued within one or more cultures (Gardner, 2011). On his review of earlier studies of intelligence and cognition, he has suggested the existence of a number of intellectual strengths, or competences, where each of which may have its own developmental history (Gardner, 2011). In essence, student's intelligence quotient (IQ) is no longer considered as the only factor that determines success in language learning, there are still many various bits of intelligence involves visual-spatial, bodily-kinesthetic, musical-rhythmic, natural, and two remaining are interpersonal and intrapersonal intelligence.

Gardner's theory is proven by some schools which applied to MI (Multiple Intelligences) program. In 1992 for example, Skyview Junior High School in Bothell, Washington assessed the MI program in its curriculum. In this school, the teachers teach the students based on their strongest intelligences areas. The results were in the four categories tested, Skyview students scored higher than the five other junior high schools in the North-shore School District. Percentage of the achievement in other junior high schools across the state meeting the WASL (Washington Assessment of Student Learning) 
Standard is: reading $38.4 \%$, writing $31.3 \%$, math $20.1 \%$, and listening $80.2 \%$, while the percentage of Skyview's students meeting the WASL Standard is: reading 61.5\%, writing 48.6\%, math 36.6\%, and listening 92.6\% (Cambell \& Cambell, 1999: 50). It was such a valid proof that students' learning achievements are not only influenced by their IQ only, but also by the other various intelligence areas.

Goleman ("Working with Emotional Intelligence Summary," n.d.) is in line with Gardner, he bravely says that Intelligence Quotient (IQ) only influences $25 \%$ on the success, whereas $75 \%$ is endorsed by other factors, one of them is EI (Emotional Intelligence) or EQ (Emotional Quotient). EQ is an intelligence that deals with emotional processing. Two types of personal intelligence, those are interpersonal and intrapersonal intelligence are laden with this type (Brown, 2007: 108).

There are some proofs about the impact of EQ as well as interpersonal and intrapersonal intelligence on language learning. For example, In International Journal of Scientific \& Engineering Research Volume 3 entitles The Impact of Emotional Intelligence on Iranian EFL Learners' Listening Proficiency found that intermediate learners with a high degree of Emotional Intelligence achieve greater listening comprehension proficiency. The data analysis has shown that $\mathrm{P}=0.000$, considering $\alpha=0.005, \mathrm{P}<0.05$, thus, EI has a great impact on listening proficiency (Seyedi, 2012: 9). It shows that Emotional intelligence has a positive correlation with listening proficiently.

Reza Pishghadam (2009: 36), a student of Ferdowsi University of Mashhad, Iran found in the result of his research that there are significant correlations between intrapersonal abilities and speaking skill ( $\mathrm{r}=.19$ ), and slightly lower correlations were found between interpersonal abilities and speaking skill $(\mathrm{r}=.11)$. It proves that there is a relationship between interpersonal and intrapersonal intelligence to the students' speaking skills.

Let's break the two personal intelligence above. Interpersonal intelligence refers to a person's ability to interact with and understand other people and social situations. Students who have strong interpersonal intelligence enjoy with other students, communication, and leadership. Interpersonal learners love to interact and prefer learning through interpersonal communication and interaction (Pritchard, 2009: 34). They also enjoy school activities such as speech, drama, and debate team (Logsdon, 2013). It has been affirmed that interpersonal students have good sociability. They are sociable and willing to interact freely with others. They are predicted to be more successful at learning a second language than the students who are more reserved (R. C. Gardner, 1985: 31). While intrapersonal students refer to students who have high self-motivation, no dependent to the other, awareness of one's own feeling more than those to others, often seen as shyness (Pritchard, 2009: 34). Intrapersonal students are more passive, they dislike working with others, they like working alone and studying alone.

In a matter of fact, students do the educational activity "learning", but they also do other activities like playing and socializing with their friends. Based on the fact and 
researcher's personal experience which happened in STAIN Pamekasan, there are some students who have strong interpersonal intelligence, they are very good at socializing. They have many friends or best friends. They love to interact much with their friends even with their teachers. In contrast, some of the students are intrapersonal, they are more passive. They prefer to do their activities by themselves.

In speaking class, most interpersonal students are usually braver to speak, and they are always ready if the teacher asks them to speak. When they make some mistakes, and their friends laugh at them, they are usually not shy since they are able to respond to them effectively. Different from intrapersonal students who are shyer and usually more introvert or closed. They are usually difficult to speak English. Consequently, they fail in speaking skill.

It is in harmony with Novita's statement. She said she has many friends who have different characteristics. Some of them enjoy gathering with their friends, meanwhile, the others love to be alone. When I asked her who is usually better in speaking? She said that usually, students who enjoy communicating with other students are better because usually, students who are alone are shy to speak (Suspriatin, 2013).

The researcher believes what is stated by Linda Campbell, Bruce Campbell, and Gardner that different intelligence will give effect the different academic achievement is right. Based on all of the phenomena which happened in STAIN Pamekasan, the Researcher is interested in executing "a Comparative Study on English Speaking Skill between Interpersonal Students and Intrapersonal Students". The main goal of this study is to answer the questions of do interpersonal students at the third semester of English Teaching Learning Program of STAIN Pamekasan academic years 2013-2014 have better English speaking skill than intrapersonal students at the same level? and the second is how statistically significant is the difference between interpersonal students and intrapersonal students at the third semester of English Teaching Learning Program of STAIN Pamekasan academic years 2013-2014 on their English speaking skill?

\section{LITERATURE REVIEW}

\section{Slight Overview of Interpersonal and Intrapersonal Intelligence}

a. Interpersonal Intelligence

Alan Pritchard states interpersonal intelligence (people smart) is related to relationships with others and various means of communication, people who are interpersonal usually enjoyment of and facility with other people, communication, leadership, and the ability to empathize (Pritchard, 2009: 52). Intrapersonal intelligence refers to the ability to understand, to communicate, and to enjoy with other people easily.

According to Suharnan in Faisal (2012) states that interpersonal intelligence is the ability to understand other people, their thought, and their feelings. Safaria in Faisal 
(2012) further defines interpersonal intelligence is as the ability to make a social relationship with other people, and those relationships will bring benefits for all (Faisal, 2012). Someone who is interpersonal will be able to build effective communication by other people, empathy, and making a harmonious relationship.

The Dimension of Interpersonal Intelligence

According to Safaria as quoted by Faisal (2012), interpersonal intelligence has three main dimensions. They are:

\section{1) Social Sensitivity}

Social sensitivity is defined as an ability to feel and to notice other reactions or change that shown verbally or nonverbally (Faisal, 2012). The individual who possesses high social sensitivity can comprehend and realize the reaction from other people easily, whether it is positive or negative. They can feel what other people feel, or we can call it as sympathy and empathy.

2) Social Insight

It is referred to as an ability to understand and to find effective problem-solving in social interaction, therefore, no problem will be delayed, even more destroying the social relationship that has been built (Faisal, 2012). It seems to be the core dimension of interpersonal intelligence. The students with this ability are able to find the solution easily. They are matched to be good leaders in a community, their social insight helps them to lead their team (their peers or their members) well.

3) Social Communication

It represents the individual's ability to use the communication process to build a healthy interpersonal relationship (Faisal, 2012). In creating, building, and maintaining a social relationship, the individual needs a communication process whether it is verbal or non-verbal communication. Therefore, it is not strange if interpersonal students possess the effective listening skill, effective speaking skill, and maybe effective writing skill.

b. Intrapersonal Intelligence

Pritchard (2009: 53) defines intrapersonal intelligence (self-smart) as intelligence which is related to self-reflection and self-awareness. Contrast with interpersonal students who enjoy interacting with other people, intrapersonal intelligence is enjoying more and facility with self-motivation, no dependence to the others, aware of one's own feeling more than those of others, often seen as shyness.

Gardner as cited by (Baum, Vens, \& Slatin, 2005: 18) states.

"Intrapersonal intelligence, (self smart) refers to having an understanding of yourself, of knowing who you are, what you can do, what you want to do, how you react to things, which things to avoid, and which things to gravitate toward. We are drawn to people who have a good understanding of themselves because people tend not to screw up." 
As a conclusion, intrapersonal intelligence is the ability to understand them-selves well and better than other people, these cases make them tend to be independent person, they will believe more about their own strengths and weaknesses.

\section{The Three Aspects of Intrapersonal Intelligence}

Harry Alder in Setyono (2009) provides three aspects of Intrapersonal intelligence. 1) Understanding/ knowing of oneself

It refers to self-comprehending. People with intrapersonal intelligence may have an accurate picture of oneself. They aware of own strength and weaknesses, awareness of inner moods, intention, motivations, temperaments, and desires, show confidence in their abilities, express feeling accurately, and also has strong willed and independent.

2) Understanding/ knowing what is wanted

Intrapersonal people may have the ability to know about their own purposes of life and their personal intentions. They have characteristics like setting their own personal goals, like or dislike of particular activities, and they really trust their instincts.

3) Understanding/ knowing what is important

It means the one who are intrapersonal has ability to comprehend well which things are important and which thing to avoid. Therefore, intrapersonal person will not do something before they are sure it is really important to do.

\section{Preferences of Interpersonal and Intrapersonal Students}

There are some preferences of interpersonal and interpersonal students given by some experts. Those involve the descriptions or dominant characteristics that can be easily seen.

\section{a. Preferences of Interpersonal Students}

Interpersonal students like to have lots of friends, talk to people, solve problems and join groups. They are good at understanding other people's feelings, leading others, organizing and communicating, they enjoy school activities such as speech, drama, and debate teams (Logsdon, 2013). They usually show great empathy to the other, giving advice to their friends, etc. Interpersonal students need to interact much with their friends to be most successful while processing the information. Learning best by: sharing, comparing, relating and talking.

b. Preferences of Intrapersonal Students

Pritchard (2009) said Intrapersonal students like to work alone and pursue own interests, daydream. They are good at understanding self, focusing inwards on feelings and dreams, following instincts, pursuing interests/goals and being original. Learn best by: working alone, individualized projects, self-paced instruction and having own space. We can infer that intrapersonal students regard their individuals as an individual which does not always depend on other people. 


\section{Reasons Why Interpersonal Students are predicted to be better on English Speaking Skill than Intrapersonal Students}

There is no implicit theory that states interpersonal students have better speaking skills than intrapersonal students. But, there are some characteristics of interpersonal students that make them tend to be better on speaking skill. First, Interpersonal students are more sociable and willing to interact freely with others. Students who are interpersonal spend their time much with socializing and interaction with their friends. Positive socialization and interaction lead them to become better students. In speaking, the students need self-confidence, managing emotion, understanding the listeners, and having a broad insight, etc. Those all automatically develop if the students socialize and interact frequently with other peers.

Second, they have good Self Disclosure or the ability to open their selves to the other people. Lumsden (as cites by (Gainau, 2009: 2)) says Self Disclosure can help someone to make good communication and relationship with other people, increasing self-confidence. Even more, it can free from feeling guilty and worry. Those functions indirectly support their speaking skill. It differs from intrapersonal students who are more reserved for other people. They usually worry and are afraid to put forward their opinion and suggestions, even to speak in front of the class. The third, Interpersonal students have high social communication skill includes the ability to listen, to write, and to speak effectively.

The fourth, as Armstrong states that interpersonal students are able to comprehend and collaborate with other people. In the process of practice speaking skill, the collaborative ability is important. Collaborating with other people will develop the students' competences. Through collaboration, they can exchange their thoughts, feeling, and ideas with their peers. They can talk and chat using English, they will get peers corrective feedback there. The last, Interpersonal students are more creative, as Freud in (Aziz, Joharman, \& Suryandari, 2013) says that creativity will appear along with the knowledge that is received via socialization with the environment. In short, the community can develop our creativity.

\section{METHOD}

The quantitative approach is applied and it was designed ex-post-facto namely causalcomparative. Causal comparative or ex post facto is a research design that has purpose to investigate the cause-and-effect relationship between independent and dependent variables.

This study focuses on comparing the students' English speaking skill between interpersonal and intrapersonal students. The independent variable is students' interpersonal and intrapersonal intelligence, these variables can not be manipulated and conditioned by the researcher. It means the independent variable has existed naturally even before the researcher starts his study. Therefore, causal-comparative or ex post facto 
Moh Syafik, and Afifah Raihany, A Comparative Study on English Speaking Skill ...

is used since the researcher does not permit the randomization and manipulation of the independent variables, because the characteristics of variables have existed before a study begins (Ary, Jacobs, Razavieh, \& Ary, 2010: 331-332).

The population was all of the students at the third semester of English Teaching Learning Program (TBI/ Tadris Bahasa Inggris) of STAIN Pamekasan academic years 2012-2013. The total number of the population was 216 students, and they were distributed into seven classes of Speaking. They were (A, B, C, D, E, F, and G class). TBI-A consisted of 20 students, TBI-B (29 students), TBI-C (36 students), TBI-D (34 students), TBI-E (31 students), TBI-F (32 students), and the number of students in TBI-G was 34 students.

Suharsimi Arikunto proposes if the population is more than 100, It is permitted to take $10-15 \%$ or $20-25 \%$ or more (Arikunto, 2006: 134). In this case the researcher chose approximately $23 \%$ from the population. They were 50 students which then divided into 25 interpersonal students and 25 intrapersonal students. Dealing with the sample size, 50 students are representative enough to be sample of this study.

The population consisted of seven classes, one of them was excellent class (TBI-AClass). It is also predicted that level of intelligence of the students in each class is different. Since the population consisted of subclasses that may differ in the characteristic being studied, to make it fair, the stratified random sampling technique is used. This technique is very effective to ensure that subgroup within the population is proportionally represented in the sample (Latief, 2011: 184). Finally, researcher takes some interpersonal and intrapersonal students randomly and proportionally in each class.

Two kinds of research instruments were utilized to obtain the data. They were questionnaire and documentation. The validity and reliability analysis have also been analyzed to ensure that the data from those instruments have high quality.

Three steps of data collection procedures are applied. The first is spreading questionnaire to measure the students' personal intelligence. And, the second step is nonparticipant observation, it is applied to observe what tests utilized by the lecturers in measuring the students' speaking skill, the teaching activities of the classes, the rating scale of speaking. And the final step is documentation. It is taken to know the score of students' speaking skill as primary data. The chosen documents are the result of students' summative test in English speaking skill at the third semester.

This study mainly focused on the comparison between two different groups (interpersonal students as variable $\mathrm{X}_{1}$ and intrapersonal students as variable $\mathrm{X}_{2}$ ) on their English speaking skill as variable $Y$. Therefore, the researcher administered statistical analysis namely independent $t$-test. Donald Ary says an independent $t$-test is a test that divides the observed difference between the means by the different expected through chance alone (Ary et al., 2010: 171). 
The formula of the t-test is as follow:

$$
\mathrm{t}=\frac{\mathrm{M}_{1}-\mathrm{M}_{2}}{\mathrm{SE} \mathrm{E}_{\mathrm{M} 1-\mathrm{M} 2}}
$$

Where:

t $\quad=\mathrm{t}$-value

$\mathrm{M}_{1}=$ Mean score of group 1 (Interpersonal students)

$\mathrm{M}_{2} \quad=$ Mean score of group 2 (Intrapersonal students)

$\mathrm{SE}_{\mathrm{M} 1-\mathrm{M} 2}=$ Standard error difference between the mean score of group 1 and group 2.

\section{RESULTS AND DISCUSSION}

\section{Results}

a. Questionnaire Results

The total number of the students was 216 students, the researcher proceeds only 104 students who meet requirements. Based on the calculation of the students' personality intelligence test taken from the questionnaire, from 104 students, there are 61 interpersonal students and 43 intrapersonal students. The percentage of them is presented in the chart below:

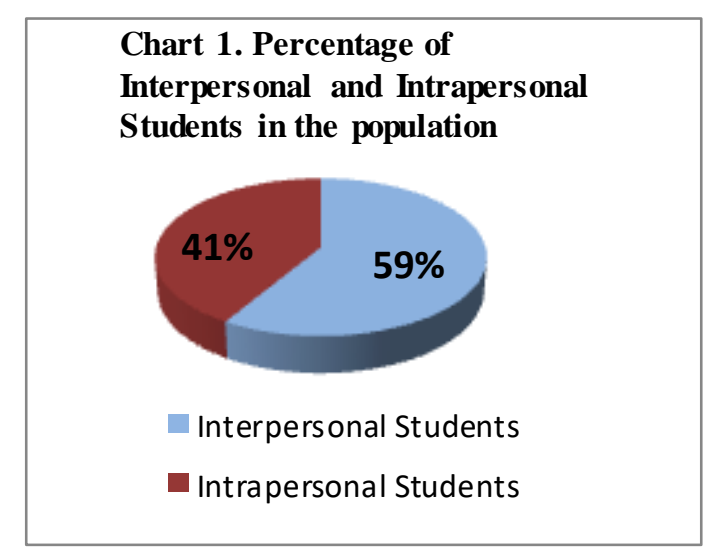

They are also classified based on gender. Of 61 interpersonal students, there are 29 female students and 32 male students. However, from 43 intrapersonal students, they are divided into 34 female students and 9 male students. See the charts below:
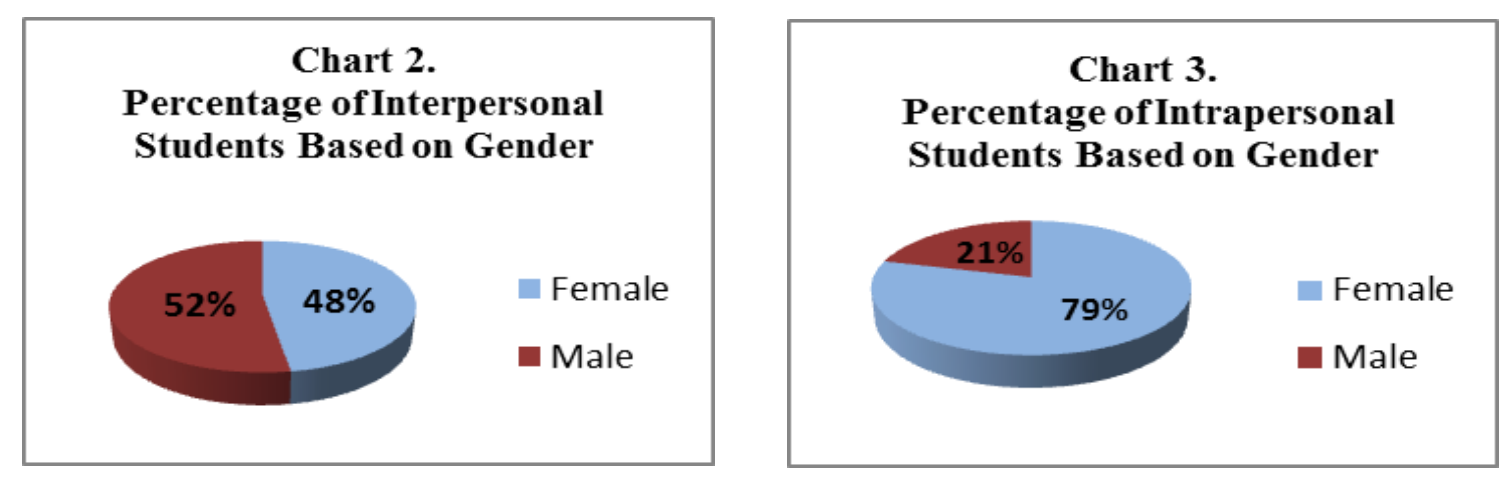
Moh Syafik, and Afifah Raihany, A Comparative Study on English Speaking Skill ...

Something unique is shown by two charts above, the percentage of interpersonal students is dominated by male students. However, the percentage of intrapersonal students is dominated by female students.

The complete data of the number of interpersonal and intrapersonal students in each class is as follow:

Table 1.

The Complete Data of Interpersonal and Intrapersonal Students in each Class.

\begin{tabular}{|c|c|c|c|c|c|c|c|c|}
\hline \multirow{3}{*}{ No } & \multirow{3}{*}{ Class } & \multicolumn{3}{|c|}{ Sum of Interpersonal Students } & \multicolumn{3}{|c|}{ Sum of Intrapersonal Students } & \multirow{3}{*}{ Sum } \\
\hline & & \multicolumn{2}{|c|}{ Gender } & \multirow{2}{*}{ Total } & \multicolumn{2}{|c|}{ Gender } & \multirow{2}{*}{ Total } & \\
\hline & & $\mathbf{F}$ & $\mathbf{M}$ & & $\mathbf{F}$ & $\mathbf{M}$ & & \\
\hline 1 & A & 5 & 6 & 11 & 3 & 0 & 3 & 14 \\
\hline 2 & $\mathrm{~B}$ & 6 & 12 & 18 & 7 & 4 & 11 & 29 \\
\hline 3 & $\mathrm{C}$ & 6 & 3 & 9 & 18 & 2 & 20 & 29 \\
\hline 4 & $\mathrm{E}$ & 4 & 2 & 6 & 2 & 2 & 4 & 10 \\
\hline 5 & $\mathrm{~F}$ & 6 & 2 & 8 & 3 & 0 & 3 & 11 \\
\hline 6 & G & 2 & 7 & 9 & 1 & 1 & 2 & 11 \\
\hline Total & & 29 & 32 & 61 & 34 & 9 & 43 & 104 \\
\hline
\end{tabular}

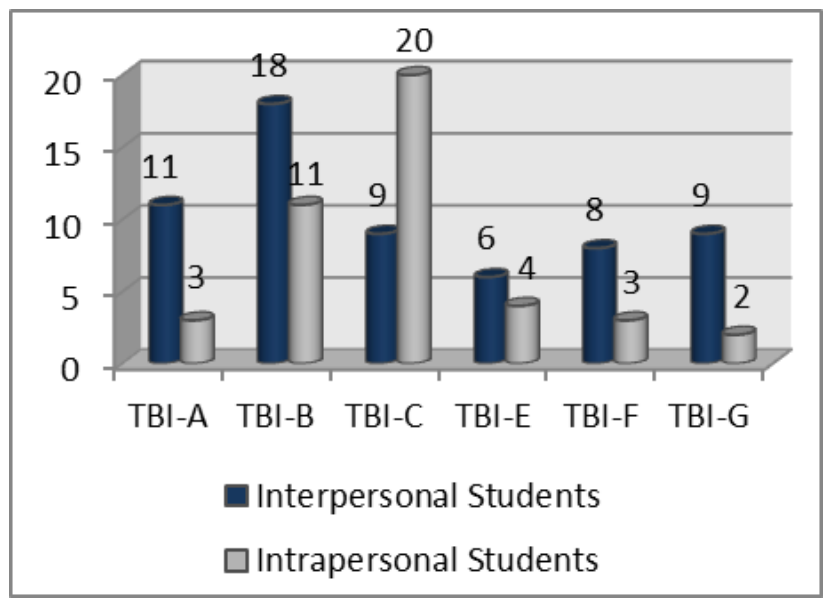

Chart 4 The Numbers of Interpersonal and Intrapersonal Students in each Class

Chart 4 shows that the numbers of interpersonal students are more dominant than intrapersonal students almost in each class. Only in C-class that the numbers of intrapersonal students are bigger than interpersonal students.

\section{b. Result of Documentation}

1) The score of speaking skill in independent variables group 1 (Interpersonal Students)

From 25 interpersonal students, it is obtained that the sum of the final score of their speaking skill is 1994. The highest score in group I is 95 and the lowest score is 68, with the median is 80 . See table below: 
Table 2.

The Speaking Skill Score of Group 1 (Interpersonal Students)

\begin{tabular}{|c|c|c|c|c|c|c|c|c|c|c|}
\hline \multirow[b]{2}{*}{ No } & \multirow{2}{*}{ Class } & \multirow{2}{*}{ Students } & \multirow{2}{*}{$\mathbf{F} / \mathbf{M}$} & \multicolumn{5}{|c|}{ Components } & \multirow{2}{*}{ Total Score } & \multirow{2}{*}{ Final Score } \\
\hline & & & & $\mathbf{P}$ & G & $\mathbf{V}$ & $\mathbf{F}$ & C & & \\
\hline 1. & A & $\mathrm{SIH}$ & M & 95 & 95 & 95 & 95 & 95 & 475 & 95 \\
\hline 2. & A & SR & M & 85 & 80 & 80 & 80 & 80 & 405 & 81 \\
\hline 3. & A & $\mathrm{AR}$ & $\mathrm{F}$ & 90 & 90 & 90 & 90 & 90 & 450 & 90 \\
\hline 4. & $\mathrm{~B}$ & Ang & $\mathrm{F}$ & 80 & 80 & 80 & 95 & 90 & 425 & 85 \\
\hline 5. & $\mathrm{~B}$ & IS & M & 72 & 72 & 72 & 72 & 73 & 361 & 72 \\
\hline 6. & $\mathrm{~B}$ & KS & $\mathrm{F}$ & 86 & 80 & 86 & 80 & 80 & 412 & 82 \\
\hline 7. & B & $\mathrm{ABH}$ & M & 78 & 78 & 78 & 80 & 80 & 394 & 79 \\
\hline 8. & $\mathrm{~B}$ & $\mathrm{SH}$ & M & 83 & 80 & 80 & 80 & 85 & 408 & 82 \\
\hline 9. & B & VSS & $\mathrm{F}$ & 80 & 80 & 80 & 80 & 80 & 400 & 80 \\
\hline 10. & B & $\mathrm{Mz}$ & M & 80 & 80 & 80 & 80 & 80 & 400 & 80 \\
\hline 11. & B & KUS & M & 80 & 75 & 75 & 78 & 75 & 383 & 77 \\
\hline 12. & $\mathrm{C}$ & $\mathrm{Mw}$ & M & 70 & 70 & 70 & 75 & 70 & 355 & 71 \\
\hline 13. & $\mathrm{C}$ & $\mathrm{MH}$ & M & 80 & 80 & 80 & 80 & 80 & 400 & 80 \\
\hline 14. & $\mathrm{C}$ & YS & $\mathrm{F}$ & 75 & 75 & 80 & 75 & 75 & 380 & 76 \\
\hline 15. & $\mathrm{C}$ & IK & $\mathrm{M}$ & 73 & 70 & 75 & 70 & 70 & 358 & 72 \\
\hline 16. & $\mathrm{C}$ & LM & $\mathrm{F}$ & 70 & 78 & 80 & 78 & 80 & 386 & 77 \\
\hline 17. & $\mathrm{C}$ & LQi & $\mathrm{F}$ & 70 & 70 & 70 & 70 & 73 & 353 & 71 \\
\hline 18. & $\mathrm{C}$ & SQL & $\mathrm{F}$ & 65 & 65 & 68 & 70 & 70 & 338 & 68 \\
\hline 19. & $\mathrm{E}$ & RW & $\mathrm{F}$ & 84 & 85 & 85 & 86 & 85 & 425 & 85 \\
\hline 20. & $\mathrm{E}$ & NCU & $\mathrm{M}$ & 80 & 79 & 80 & 90 & 90 & 419 & 84 \\
\hline 21. & $\mathrm{E}$ & $\mathrm{KN}$ & $\mathrm{F}$ & 80 & 78 & 85 & 90 & 90 & 423 & 85 \\
\hline 22. & $\mathrm{~F}$ & $\mathrm{Nj}$ & $\mathrm{F}$ & 78 & 77 & 80 & 80 & 83 & 398 & 80 \\
\hline 23. & $\mathrm{~F}$ & SLF & $\mathrm{F}$ & 85 & 80 & 85 & 90 & 90 & 430 & 86 \\
\hline 24. & $\mathrm{G}$ & AZR & $\mathrm{M}$ & 77 & 77 & 77 & 85 & 86 & 402 & 80 \\
\hline 25. & G & SM & $\mathrm{F}$ & 75 & 74 & 77 & 77 & 78 & 381 & 76 \\
\hline Sum & & & & & & & & & 9961 & 1994 \\
\hline
\end{tabular}

Note :

P : Pronunciation

G : Grammar

V : Vocabulary

F : Fluency

C : Comprehension

Table 2.1

Description of Data of Speaking Skill Score of Group 1 (Interpersonal Students)

\begin{tabular}{lccccccc}
\hline Description & Max & Min & Range & Mean & Median & Variance & Std. Deviation \\
\hline Group 1 & 95.00 & 68.00 & 27.00 & 79.760 & 80.000 & 39.357 & 6.27349 \\
Total & 95.00 & 68.00 & 27.00 & 79.760 & 80.000 & 39.357 & 6.27349 \\
\hline
\end{tabular}


Moh Syafik, and Afifah Raihany, A Comparative Study on English Speaking Skill ...

2) The score of speaking skill in independent variables group 2 (Intrapersonal Students)

From 25 intrapersonal students, the researcher obtains sum of final speaking scores of group 2 (intrapersonal students) is 1814, the maximum score is 87 and the minimum score is 56 . The median was 72 . It can be seen in the following table.

Table 3.

The Speaking Skill Score of Group 2 (Intrapersonal Students)

\begin{tabular}{|c|c|c|c|c|c|c|c|c|c|c|}
\hline \multirow{2}{*}{ No } & \multirow{2}{*}{ Class } & \multirow{2}{*}{ Students } & \multirow{2}{*}{$\mathbf{F} / \mathbf{M}$} & \multicolumn{5}{|c|}{ Components } & \multirow{2}{*}{ Total Score } & \multirow{2}{*}{ Final Score } \\
\hline & & & & $\mathbf{P}$ & G & $\mathbf{V}$ & $\mathbf{F}$ & C & & \\
\hline 1. & A & $\mathrm{Rq}$ & $\mathrm{M}$ & 83 & 85 & 85 & 83 & 85 & 421 & 84 \\
\hline 2. & A & SM & M & 85 & 85 & 85 & 90 & 90 & 435 & 87 \\
\hline 3. & A & ES & $\mathrm{F}$ & 80 & 80 & 80 & 80 & 80 & 400 & 80 \\
\hline 4. & B & Sus & $\mathrm{F}$ & 70 & 70 & 70 & 70 & 70 & 350 & 70 \\
\hline 5. & B & NFK & M & 70 & 70 & 70 & 70 & 70 & 350 & 70 \\
\hline 6. & B & AFA & $\mathrm{F}$ & 60 & 50 & 60 & 55 & 55 & 280 & 56 \\
\hline 7. & B & YP & M & 65 & 60 & 60 & 65 & 65 & 315 & 63 \\
\hline 8. & $\mathrm{~B}$ & FS & M & 70 & 70 & 70 & 72 & 72 & 354 & 71 \\
\hline 9. & B & MT & $\mathrm{F}$ & 80 & 75 & 75 & 80 & 75 & 385 & 77 \\
\hline 10. & B & Msd & M & 75 & 75 & 75 & 75 & 75 & 375 & 75 \\
\hline 11. & B & MAS & M & 80 & 80 & 80 & 86 & 90 & 416 & 83 \\
\hline 12. & $\mathrm{C}$ & Ly & M & 72 & 73 & 71 & 70 & 75 & 361 & 72 \\
\hline 13. & $\mathrm{C}$ & DH & $\mathrm{M}$ & 65 & 65 & 63 & 60 & 65 & 318 & 64 \\
\hline 14. & $\mathrm{C}$ & LRD & $\mathrm{F}$ & 65 & 65 & 65 & 60 & 70 & 325 & 65 \\
\hline 15. & $\mathrm{C}$ & SW & M & 70 & 75 & 75 & 75 & 80 & 375 & 75 \\
\hline 16. & $\mathrm{C}$ & SA & $\mathrm{F}$ & 70 & 70 & 70 & 70 & 70 & 350 & 70 \\
\hline 17. & $\mathrm{C}$ & Kw & $\mathrm{F}$ & 70 & 70 & 70 & 70 & 70 & 350 & 70 \\
\hline 18. & $\mathrm{C}$ & NS & $\mathrm{F}$ & 70 & 70 & 70 & 70 & 70 & 350 & 70 \\
\hline 19. & $\mathrm{E}$ & $\mathrm{MH}$ & $\mathrm{F}$ & 69 & 68 & 70 & 70 & 70 & 347 & 69 \\
\hline 20. & $\mathrm{E}$ & $\mathrm{AM}$ & M & 75 & 75 & 77 & 80 & 80 & 387 & 77 \\
\hline 21. & $\mathrm{E}$ & $\mathrm{HJ}$ & $\mathrm{F}$ & 70 & 70 & 73 & 74 & 75 & 362 & 72 \\
\hline 22. & $\mathrm{~F}$ & DP & $\mathrm{F}$ & 75 & 75 & 77 & 80 & 80 & 387 & 77 \\
\hline 23. & $\mathrm{~F}$ & LZS & $\mathrm{F}$ & 70 & 70 & 70 & 75 & 75 & 360 & 72 \\
\hline 24. & $\mathrm{G}$ & SYN & $\mathrm{M}$ & 75 & 75 & 75 & 77 & 78 & 380 & 76 \\
\hline 25. & G & SF & $\mathrm{F}$ & 68 & 68 & 70 & 70 & 70 & 346 & 69 \\
\hline Sum & & & & & & & & & 9079 & 1814 \\
\hline
\end{tabular}

Note :

P : Pronunciation

G : Grammar

V : Vocabulary

F : Fluency

C : Comprehension 
Table 3.1

Description of Data of Speaking Skill Score of Group 2 (Intrapersonal Students)

\begin{tabular}{lccccccc}
\hline Description & Max & Min & Range & Mean & Median & Variance & Std. Deviation \\
\hline Group 2 & 87.00 & 56.00 & 31.00 & 72.560 & 72.000 & 47.673 & 6.90459 \\
Total & 87.00 & 56.00 & 31.00 & 72.560 & 72.000 & 47.673 & 6.90459 \\
\hline
\end{tabular}

Data Analysis

It is the result of data analysis through formula of independent t-test available at SPSS.

Table 4.

The Result of $t$-test by using SPSS 16

\begin{tabular}{llllll}
\hline Description & Name of Group & N & Mean & Std. Deviation & Std. Error Mean \\
\hline Speaking & A & 25 & 79.7600 & 6.27349 & 1.25470 \\
Score & B & 25 & 72.5600 & 6.90459 & 1.38092 \\
\hline
\end{tabular}

Leevene's Test for

Equality of Variances

t-test for Equality of Means

\begin{tabular}{|c|c|c|c|c|c|c|c|}
\hline \multirow{2}{*}{$\mathbf{F}$} & \multirow{2}{*}{ Sig. } & \multirow{2}{*}{$\mathbf{t}$} & \multirow{2}{*}{ df } & \multirow{2}{*}{$\begin{array}{l}\text { Mean } \\
\text { Difference }\end{array}$} & \multirow{2}{*}{$\begin{array}{l}\text { Std. Error } \\
\text { Difference }\end{array}$} & \multicolumn{2}{|c|}{$\begin{array}{l}95 \% \text { Confidence Interval of } \\
\text { the Difference }\end{array}$} \\
\hline & & & & & & Lower & Upper \\
\hline \multirow[t]{2}{*}{.208} & .651 & 3.859 & 48 & 7.20000 & 1.86580 & 3.4486 & 10.9514 \\
\hline & & 3.859 & 47.56 & 7.20000 & 1.86580 & 3.4478 & 10.9523 \\
\hline
\end{tabular}

From the result of analysis of data above, the result of t-value is 3.859, or simply 3.86 . It reflects that there is difference between two means score resulted from two different groups. To further examine whether t-value shows significant difference or not, the result is consulted with critical value that is performed in t-table. By using level of significance $5 \%, 50 d f$. In the row $50 d f$, it is found that the critical value of t-table by level of significance $5 \%$ is 2.01 .

Based on the comparison, $t$-value is significantly higher than t-table in level of significance $5 \%, t_{0}>t$-table, $(3.86>2.01)$. Finally, it can be inferred that interpersonal students at the third semester of English Teaching Learning Program of STAIN Pamekasan academic years 2013 - 2014 have a better English speaking skill than intrapersonal students at the same level. 
Moh Syafik, and Afifah Raihany, A Comparative Study on English Speaking Skill ...

\section{Discussion}

a. Interpersonal students at the third semester of English Teaching Learning Program of STAIN Pamekasan academic years 2013-2014 have a better English speaking skill than intrapersonal students at the same level

It is proven by the result of statistical analysis that shows mean score of interpersonal students is 79.76, while mean score of intrapersonal students is 72.56. It reveals interpersonal students score higher than intrapersonal students on English speaking skill (79.76 > 72.56).

b. There is significant difference between interpersonal students and intrapersonal students at the third semester of English Teaching Learning Program of STAIN Pamekasan academic years 2013-2014 on their English speaking skill.

This conclusion is taken from the result of data analysis that $t$-value is higher than $t-$ table. The $\mathrm{t}$-value $=3.86$, while $\mathrm{t}$-table $=2.01$ (Level of significance $=0.05, \mathrm{df}=50) ;(3.86>$ 2.01). By looking at the differences that is 1.85 , this number shows that the difference on English speaking skill between two groups is very significant.

Furthermore, on the five components of speaking skill, interpersonal students are significantly higher than intrapersonal students. Here is the conclusion of the difference on five components of speaking skill.

Table 5.

The Conclusion of the Difference on Score of Five Components of Speaking Skill

\begin{tabular}{|c|c|c|c|c|c|c|c|}
\hline \multirow{2}{*}{ Comp } & \multirow{2}{*}{$\overline{\mathrm{X}}_{1}$} & \multirow{2}{*}{$\overline{\mathrm{X}}_{2}$} & \multirow{2}{*}{ Mean Difference $\left(\overline{\mathrm{X}}_{1}-\overline{\mathrm{X}}_{2}\right)$} & \multirow{2}{*}{ t-value } & \multicolumn{2}{|c|}{ t-table $(d f=50)$} & \multirow{2}{*}{ Conclusion } \\
\hline & & & & & $5 \%$ & $1 \%$ & \\
\hline $\mathrm{P}$ & 78.84 & 72.08 & 6.76 & 3.724 & 2.01 & 2.68 & Significant \\
\hline G & 77.92 & 71.56 & 6.36 & 3.281 & 2.01 & 2.68 & Significant \\
\hline $\mathrm{V}$ & 79.52 & 72.24 & 7.28 & 4.073 & 2.01 & 2.68 & Significant \\
\hline $\mathrm{F}$ & 81.04 & 73.08 & 7.96 & 3.623 & 2.01 & 2.68 & Significant \\
\hline $\mathrm{C}$ & 81.12 & 74.20 & 6.92 & 3.267 & 2.01 & 2.68 & Significant \\
\hline
\end{tabular}

One of the characteristic of interpersonal students is they love interacting much with other people. Rivers says through interaction the students can exploit the elasticity of language. It means interpersonal students should be better on speaking skill especially on the Fluency component. Table 6 has proved it. On five components of speaking skill, interpersonal students are better, especially on Fluency (F), as finding the highest mean difference is on fluency.

The case of the function of interaction is also explained by Richard and Willy A Renandya (Richards \& Renandya, 2002: 208). They say that interaction is the key to improving students' speaking ability: 
"Out of interaction, learners will learn how to communicate verbally and nonverbally as their language store and language skills develop. Consequently, the give and task exchanges of messages will enable them to create a discourse that conveys their intention in real-life communication."

The statement above sustains that Interaction is important not only to exploit the elasticity of language as Rivers says, but also to support the student to be more capable of developing their language skills. Through interaction, the students will get a better comprehension of certain problems if they used to interact with other people. They will able to send their ideas effectively like in real-life communication. Moreover, interaction is the heart of communication, and most of the communication is in the form of speaking. Therefore, the frequency to interact will influence the success of our speaking skill. All of the statements above have explained why interpersonal students (who are more interactive) have better speaking skill than intrapersonal students.

Secondly, there is a natural link between speaking and listening. When someone speaks, the other students will listen naturally. Speaking is the communicative skill in which it must involve within one or more participants. Therefore, an understanding of all audiences is very essential. Another characteristic of interpersonal students is they have high social sensitivity, it makes them have good understanding of their audiences. By understanding the audiences, interpersonal students will be more careful in diction, the vocabulary, and also the arrangement of good sentences (Grammar), in order for what they say make the audiences enjoy without any problem.

The third, Pritchard says that interpersonal students have the ability to empathize. Empathy (Guirora et al in Brown, 2007) itself is stated as "a process of comprehending in which a temporary fusion of self-object boundaries permits an immediate emotional apprehension of the affective experience of another. They are able to feel what other people feeling, and they can put their selves into someone else's shoes. To deal with this case, some experts state that there is a positive relationship between Empathy and success in learning speaking.

Taylor, Catford, Guirora, and Line hypothesize that "the more sensitive an individual is to feelings and behaviors of another person, the more likely he is to perceive and recognize the subtleties and unique aspects of the second language and incorporate them in speaking (R. C. Gardner, 1985: 35)." This hypothesis is reasonable, the research literature supported it. Guirora et all obtained a rank-order correlation of .60 between scores on the MME test (the Micro-Momentary Expression test: a test to measure the empathy) and rating of the accuracy of French pronunciation of 14 French teachers (R. C. Gardner, 1985). In short, it seems to be natural that the ability of empathy of interpersonal students play pivotal rule in their successful on speaking skill, especially on pronunciation (78.84 > 72.08).

Furthermore, Brown also supports the finding of Guirora's research, he says that communication requires a sophisticated a degree of empathy. In order to communicate 
effectively, the speakers need to be able to understand the other persons' reaction to permeate their ego boundaries, so that they can send and receive message clearly (Brown, 2007: 165). Therefore, interpersonal students with high ability to empathize have better speaking skill because they can control their ego in order the information that they share can easily pass in one ear and out the other without any misunderstanding or misinterpreting of words, phrases, or the ideas.

Next, two dimensions of interpersonal intelligence are social insight and social communication. These dimensions seem to be defined as the ability of people in making social relationships. So, students who perform strongly interpersonal intelligence casually have good communication skills include a balance of listening and sharing of information to maintain mutually satisfying relationships and to relate well with others. Moreover, establishing strong interpersonal relationships at school can also enhance the student's personal and academic performance, including the speaking skill performance.

Furthermore, the probable reasons for this result finding might be due to the fact that interpersonal students have better sociability than intrapersonal students. I have based that the more sociable the students, the better their speaking skill. My reason is linear with various studies before. Pritchard (1952) reported a particularly high correlation of .94 between sociability and ratings of French fluency of 33 grammar school students (R. C. Gardner, 1985). Gardner and Lambert (1972) proved in their study that "the more socially sensitive or empathic person might be more integratively oriented or more gifted for learning the oral-aural features of a foreign language" (p. 22) (R. C. Gardner, 1985: 36). It can be concluded that sociability gives a positive effect on the improvement in speaking skill.

In addition, interpersonal students are good at building a social relationship. By doing it, they will have good self-confidence and will enrich their experience. and will enrich their experience, the speaker can increase the quality of their speaking. They can deliver their ideas and opinions effectively and convincingly.

Besides, interpersonal students are also able to work collaboratively. In the process of learning the speaking skill, the ability to collaborate with other people is important. They can work collaboratively to correct each other of their studies. It may be in the form of peer feedback activities. For instance, when the students have some mistakes in pronunciation or grammar, their friends will correct them. Linking up many critical corrections and suggestions come from many individuals is oftentimes very effective and potential.

Next, Interpersonal students are better on English speaking skill, because they have special characteristics like outgoing, and easily adaptable. Those characteristics make interpersonal students quick to learn a language (R. C. Gardner, 1985). They differ from intrapersonal students who are commonly shier. They don't want to take a risk. Therefore, 
they often need much more times to process ideas before speaking. Even sometimes they will avoid linguistic risks in conversation.

The people who exhibit interpersonal intelligence are suitable to be a teacher, counselor, business executive, and sales person (Nelson, 1998: 11). All of them require a good speaking skill of the worker. Oprah Winfrey and Martin Luther King are the example of interpersonal person who have good public speaking. However, people who are intrapersonal have good understanding one self, have a strong sense of self, are confident, and can enjoy working alone (Nelson, 1998). You can easily find this intelligence on philosopher, writers, psychologist, and scientist. The people with this intelligence are Albert Einstein and Sigmund Freud. They are usually not good public speakers because they are intrapersonal ones.

All of the facts above show that the result of this study states "students with strongly interpersonal intelligence are better on English speaking skill rather than intrapersonal students" is well received.

As a note, besides intelligence's factor, it should remind that the successful of speaking skill can't be let loose by other factors. There are internal and external factors. Internal factors involve physiological factors (body healthy, the normal activation of five senses, etc.) and psychological factors (emotion, motivation, and talent). However, External factors consist of social environments (family, school, and society) and non-social environments such as the condition of the school, the weather, and also the educational media that are available.

\section{CONCLUSION}

The research result reveals that there is a significant difference between interpersonal students and intrapersonal students at the third semester of English Teaching Learning Program of STAIN Pamekasan on their English speaking skill. The $\mathrm{t}$ value $=3.86$, while $t$-table $=2.01$ (Level of significance $=0.05, \mathrm{df}=50) ;(3.86>2.01)$. By looking at the differences that is 1.85 , this number shows that the difference on English speaking skill between two groups is very significant. This may happen because they have special characteristics, such as love doing interaction, having good communication skills, are able to empathize, and possessing good sociability. They are also usually outgoing and also easily adaptable make them quick to learn. The finding above also confirms that different intelligence of the students gives a different effect on the students' learning achievement.

\section{REFERENCES}

Arikunto, S. (2006). Prosedur Penelitian: Suatu Pendekatan Praktik (7th ed.). Jakarta: Rineka Cipta.

Ary, D., Jacobs, L. C., Razavieh, A., \& Ary, D. (2010). Introduction to research in education (8th ed). Belmont, CA: Wadsworth. 
Moh Syafik, and Afifah Raihany, A Comparative Study on English Speaking Skill ...

Aziz, K., Joharman, \& Suryandari, K. C. (2013). Hubungan Antara Kecerdasan Interpersonal, Berpikir Kreatif, dan Hasil Menulis Siswa Kelas V Sd Negeri di Kabupaten Kebumen. Kalam Cendekia PGSD Kebumen, 1(3).

Baum, S., Vens, J., \& Slatin, B. (2005). Multiple Intelligences in the Elementary Classroom (A Teacher's Toolkit). New York: Teachers College Press.

Brown, H. D. (2007). Principle of Language Learning and Teaching (5th ed.). San Fransisco: Pearson Education Inc.

Cambell, L., \& Cambell, B. (1999). Multiple intelligences and Student Achievement: Success Story from Six Schools. Virginia: ASCD.

Faisal, S. (2012). Hubungan antara Kecerdasan Interpersonal dengan Perilaku Altruisme pada Siswa Kelas $X$ di MAN 3 Kediri (Thesis). Universitas Islam Negeri Maulana Malik Ibrahim.

Gainau, M. B. (2009). Keterbukaan Diri (Self Disclosure) Siswa dalam Perspektif Budaya dan Implikasinya bagi Konseling. Jurnal Ilmiah Widya Warta, 33(1), 95-112.

Gardner, H. (1983). Frames of Mind. New York: A Member of the Perseus Books Group.

Gardner, R. C. (1985). Social Psychology and Second Language Learning: The Role of Attitudes and Motivation. London: E. Arnold.

Latief, M. A. (2011). Research Methods on Language Learning: An Introduction. Malang: University Negeri Malang Press.

Logsdon, A. (2013). Learning Disabilities. Retrieved March 6, 2020, from http://learningdisabilities.about.com/od/resourcesresearch /qt/interpersonal.htm

Nelson, K. N. (1998). Developing Students Multiple Intelligences. New York: Scholastic Press.

Pishghadam, R. (2009). A Quantitative Analysis of the Relationship between Emotional Intelligence and Foreign Language Learning. Electronic Journal of Foreign Language Teaching, 6(1), 31-41.

Pritchard, A. (2009). Ways of Learning. London: Routledge.

Richards, J. C., \& Renandya, W. A. (2002). Methodology in Language Teaching: An Anthology of Current Practice. Cambridge: Cambridge University Press.

Setyono, I. D. (2009). Pengaruh Kecerdasan Intrapersonal dan Media Pembelajaran Powerpoint terhadap Prestasi Belajar Matematika (Skripsi). Universitas Muhammadiyah Surakarta.

Seyedi, G. (2012). The Impact of Emotional Intelligence on Iranian EFL Learners' Listening Proficiency. IJSER, 2(7), 1-11.

Suspriatin, N. (2013, December 4). A Third Semester Students of TBI [Interview by Phone].

Ulviana. (2011). Improving Students' Speaking Ability through Communication Games (Thesis). UIN Syarif Hidayatullah Jakarta.

Widdowson, H. G. (1978). Teaching English as Communication. New York: Oxford University Press.

Working with Emotional Intelligence Summary. (2020). Retrieved March 6, 2020, from SuperSummary website: http://www.supersummary.com/working-withemotional-intelligence/summary/ 